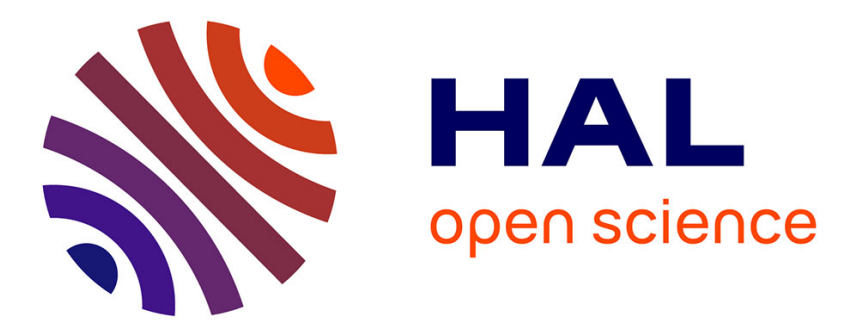

\title{
Forms and deposits of the continental quaternary of the Saharan margin of Eastern Maghreb (tentative synthesis)
}

Jean-Louis Ballais, Hédi Ben Ouezdou

\section{- To cite this version:}

Jean-Louis Ballais, Hédi Ben Ouezdou. Forms and deposits of the continental quaternary of the Saharan margin of Eastern Maghreb (tentative synthesis). Journal of African Earth Sciences, 1991, $12(1 / 2)$, pp.209 - 216. 10.1016/0899-5362(91)90070-F . hal-01562556

\section{HAL Id: hal-01562556 \\ https://hal-amu.archives-ouvertes.fr/hal-01562556}

Submitted on 15 Jul 2017

HAL is a multi-disciplinary open access archive for the deposit and dissemination of scientific research documents, whether they are published or not. The documents may come from teaching and research institutions in France or abroad, or from public or private research centers.
L'archive ouverte pluridisciplinaire HAL, est destinée au dépôt et à la diffusion de documents scientifiques de niveau recherche, publiés ou non, émanant des établissements d'enseignement et de recherche français ou étrangers, des laboratoires publics ou privés. 


\title{
Forms and deposits of the Continental Quaternary of the Saharan margin of Eastern Maghreb (Tentative Synthesis)
}

\author{
J. L. BALLAIS* and H. BEN OUEZDOU** \\ *Faculté des Sciences Humaines et Sociales, 94. Boulevard 9 Avril 1938, 1007 Tunis, Tunisie \\ **Centre des Sciences de la Terre, I.N.R.S.T., B.P. 95, 2050 Hammam-Lif, Tunisie
}

\begin{abstract}
The Saharan margin of Eastem Maghreb extends from Aurès in the West to the Gulf of Gabès in the East. The Plio-Quaternary boundary is very complex in the West where it is characterized by the persistence of Tertiary sedimentation with the development of ablation forms, presence of crusts and the formation of a lacustrine system. This is followed by the development of accumulation forms during the Middle Pleistocene and mostly during the Upper Pleistocene to Holocene with contemporaneous diminution in the granulometry of the deposits.

The evolution of gypcretes at the expense of calcretes crust suffered a partial reverse during the Middle Pleistocene. At this time a lacustrine phase settled down in the Algero-Tunisian Chotts (sebkhas).

The end of the Middle-Pleistocene corresponded with a major climatic break with the disappearance of the calcretes. By the end of the Upper Pleistocene, the gypcretes attained their maximum development and latter disappeared during the Holocene.
\end{abstract}

Résumé - Ce bilan provisoire s'appuie sur les connaissances acquises depuis 25 ans dans les Aurès, les Nemencha, la région des grands Chotts algéro-tunisiens, le Dahar et la plaine côtière de Gabès. Il permet de mettre en évidence l'originalité de la chamière Pliocène-Quaternaire et le rôle des variations climatiques dans l'évolution quatemaire.

La chamière Pliocène-Quaternaire montre, d'une part, la persistance de certaines caractéristiques tertiaires (continuité de la sédimentation : détritique dans la plaine côtière, lacustre dans la région des grands Chotts) et, d'autre part, l'apparition de nouvelles caractéristiques (formation de croûtes gypseuses dans la région des grands chotts et formation de croûtes calcaires ailleurs). Les formes sont plus variées à l'Ouest (pseudo-raña, glacis, coulées boueuses) qu'à l'Est (pédiment ou glacis). Une réduction du nombre des niveaux s'observe également de l'Ouest ( 3 niveaux) à l'Est (1 seul niveau).

Au Pléistocène moyen, les formes d'accumulation (glacis d'accumulation dans les Aurès, terrasse dans le Dahar et dans la plaine côtière) commencent à se substituer aux formes d' ablation (glacis d'ablation couvert). Au Pléistocène supérieurHolocène, cette tendance se généralise (terrasse, cône alluvial et épandage) à l'exception de la région des grands Chotts tunisiens.

De la même façon, la granulométrie des dépôts, grossière au Pléistocène inférieur et moyen, devient fine au Pléistocène supérieur (avec un gradient W-E) et à dominante fine à l'Holocène.

Enfin, l'évolution géochimique montre le développement progressif, au Pléistocène moyen et surtout au Pléistocène supérieur, des croûtes gypseuses (limitées aux confins des grands Chotts au Pléistocène inférieur) aux dépens des croûtes calcaires; en effet, si les deux types de croûtes altement encore au Pléistocène moyen, les croûtes gypseuses dominent totalement au Pléistocène supérieur (sauf dans les Matmata) avant de disparaître au cours de l'Holocène.

Cette évolution met en évidence l'existence d'une coupure climatique fondamentale à la fin du Pléistocène moyen et d'autres moins importantes à la fin du Pléistocène inférieur et à la fin du Pléistocène supérieur. L'absence d'une phase lacustre au Pléistocène moyen posait donc un problème majeur et se trouvait en contradiction avec les caractéristiques climatiques de cette période. Des datations radiométriques $(T / U)$ ont permis récemment de confirmer l'existence d'une telle phase.

\section{INTRODUCTION}

Since the last 25 years, knowledge of the continental Quaternary of the Saharan margin of Eastern Maghreb has increased considerably. It is now possible to attempt a review of the Quaternary geology of the region extending from Aurès in the west to the Gulf of Gabès in the east (see Fig. 1). The area can be subdivided into six distinct morphotectonic zones as follows: Aurès, Nemencha, Tunisian saline lakes or Chotts, Dahar, Matmata basins and the coastal plain of Gabès. This study, reveals the similarities in these zones that are probably due to Quaternary climatic varlations as well as differences in other regional parameters.

\section{FROM THE SOUTHERN PIEDMONT OF THE AURES TO THE GULF OF GABES: REGIONAL PRESENTATION OF THE CONTINENTAL gUATERNARY}

The Southern Pledmont of the Aures (Ballais,
1884)

The Pliocene-Quaternary boundary - The end of the Pliocene sedimentation (1000 $\mathrm{m}$ total thick- 


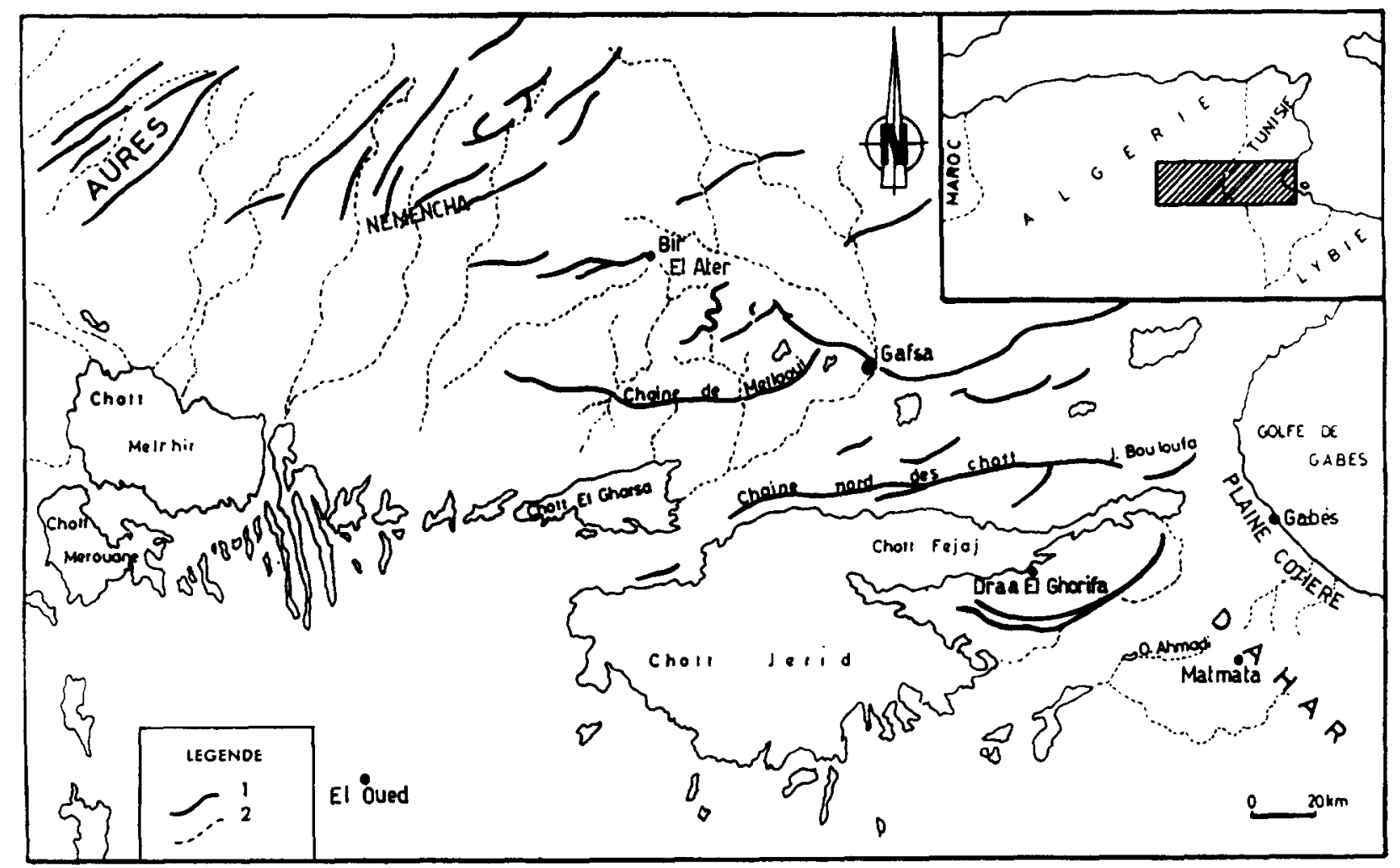

Fig. 1. Location map. 1 - main reliefs, 2 - limit of morphotectonic zones.

Fig. 1. Carte de localisation. 1 - reliefs principaux; 2 - limite de zone morphotectonique.

ness) is characterized by 200 to $300 \mathrm{~m}$ of conglomerates (Guiraud, 1973) probably contemporaneous with the first lacustrine phase in the Melrhir and Merouane Chotts. As well as the preceeding deposits, they are affected by the tectono-orogenic phase of the Lower Quaternary.

A convex-shaped pseudo-raña was locally deposited later with a length of $1 \mathrm{~km}$, width of $20 \mathrm{~m}$ at the upstream end and a few meters at the downstream end. It consists of blocks that can attain several cubic meters, often round, loose, covered by a calcrete. By a dip of $6 \%$ it truncates the Cenomanian limestone which have been vertically redressed, over $300 \mathrm{~m}$ above the beds of the present day wadis.

The Lower Pleistocene - The Lower Pleistocene is characterized by alternation of glacis and mud flows. The oldest Glacis (Glacis, VI) younger than the Lower Acheulian (Ballais, 1984), is represented by some scattered mounds with several meters of cover consisting of large blocks close to the relief. This covered ablation glacis-fan changes eastward into accumulation glacis or fan. The characteristic calcacrete at the top in the west is initially covered by gypsiferous encrusting and then by a gypcrete which remains exclustve south of Nemencha. Mud flows of several kilometers long and several tens of meters thick containing large blocks of several cubic meters and with a calcrete at the top are subsequently emplaced. The second glacis (Level $\mathrm{V}$ ) is well represented. It is generally an ablation glacisfan covered by blocks and pebbles sometimes strongly consolidated by a calcareous cement. A second generation of mud flows is emplaced with the same characteristics as the first.

The Middle Pleistocene - It is during this period that the glacis attained their maximum extension. The mud flows dissapear as the terraces develop and the eolian sediments accumulate in the west.

The glacis IV is well developed and is often an accumulation glacis-fan (of about $10 \mathrm{~m}$ of large stones, bedded, alternating with silt, sands and gravels). It grades laterally into "épandages" or cover ablation glacis. It is replaced by the last series of mud flows still several kilometers in length but only 10 to $20 \mathrm{~m}$ thick with no terminal crust.

The pre Middle Paleolithic Glacis (III) is less developed. It is an accumulation glacis-fan or a glacis - terrace and occasionally a covered ablation glacis-fan. It is only covered by a gypcrete in the west and passes laterally into alluvial fans or a very restricted terrace. Finally, a lacustrian phase could be produced in the Melrhir and Merouane Chotts (Ballais et al., 1985).

The Upper Pleistocene - This was a period of limited deposition and geomorphologic forms. Glacis II, the last glacis-terrace of same age, often constitutes the principal terrace. It generally possesses a gypcrete. Downstream it grades into a much finner fan. A second lacustrian phase is thus 
developed in the Melrhir and Merouane Chotts (Coque et Gachelin, 1975).

The Holocene - This is a period of complex deposition (Ballais, 1986) characterzed by the setting up of new eolian accumulations throughout the Lower Sahara (Ballais et Benazzouz, 1987). It is followed by the accumulation of a terrace (often subdivided into 2) several meters high or stony fans which downstream grade into large extensive and more functional playas.

\section{THE REGION OF THE LARGE TUNISIAN CHOTTS (Coque, 1862)}

\section{The Pllocene-guaternary boundary}

The Tertiary ended with the deposition of the Continental Terminal Complex consisting of several hundreds of meters of sandstones, clays and conglomerates. Three regional types can be distinguished. At the top, gypsiferous deposits containing Cerastoderma glaucum representing a first "lagoonal" phase dated as Lower Villafranchian from mammalian fauna at Ain Brimba. These deposits were often deformed during a Villafranchian tectono-orogenic phase.

\section{The Middle Pleistocene}

It is characterized by the development of glacis 4 and 3. Glacis 4 is limited to a few mounds in front of Jebel Tebaga and is covered by gypcrete. The ablation Glacis $3(0,50 \mathrm{~m}$ to $6 \mathrm{~m}$ of heterometric cover consisting of the most rounded and the less flat pebbles in all the $\mathbf{4}$ glacis), consits mainly of mounds or interfluves covered by a gypcrete. It grades into a terrace near the wadis. The cover revealed an Acheulian industry.

\section{The Upper Pleistocene}

Glacis 2 is generally the most developed. The cover $(0.50 \mathrm{~m}$ to $5 \mathrm{~m})$ consists of fewer rounded and relatively more flat stones than the precedent. It passes laterally into a terrace. A Mousterlan industry characterizes the base of the cover while a bladelet industry is present towards the top.

A second "lagoonal" phase with Cerastoderma glaucum is contemporaneous with the development of this glacis. The gypcrete which later seals the cover, equally fossilizes the dunal accumulations south of the Chotts.

\section{Holocene}

Glacis 1 developed during the Holocene. It is well developed at the foot of the high chains and around the base level but is also a simple terrace along the wadis. Its coarse-grained cover $(0,50 \mathrm{~m}$ to $2 \mathrm{~m})$ does not contain a gypcrete but locally silty gypseous sands of 1 to $2 \mathrm{~m}$ thickness.
Cartographic studies and recent geomorphologic observations has led to new data on this region. In fact around the piedmont south of Jebel Chebket Bouloufa (North chain of the Chotts), the cover of the highest ablation glacis (Glacis 3) is characterized by a calcareous cement with a calcrete (Abbes et al., 1986). A conglomerate with calcareous cement (capping glacis 3?) truncate the Lower Cretaceous sandstones of Draa el Ghorifa (Southern bank of Fejaj Chott). Elsewhere, in certain sectors like the southern piedmont of the Metlaoui Chain, five Quaternary levels can be recognized. (Ben Ouezdou et Zargouni, 1988). A low terrace and a glacis, with coarse grained materlals without encrusting succeed two Glacis-fans with gypcretes. Finally, a conglomerate with calcareoussandstone cement with Levallois industry constitutes the oldest level.

\section{THE WESTERN MARGIN OF DAHAR (Coque, 1962)}

\section{The Lower Pleistocene}

During the Lower Pleistocene a pediment developed on the Senonian limestones with a slight dip towards the west. A zoned fragmented calcrete (reg) overlies the calcareous substratum. Near the axes of the main wadis, the Lower Pleistocene consists of a very consolidated conglomerate with angular calcareous stones (Coque, 1962).

\section{The Middle Pleistocene}

The Middle Pleistocene consists of a terrace about $5 \mathrm{~m}$ high with coarse-grained deposits containing pebbles 10 to $20 \mathrm{~cm}$ long cemented into a conglomerate. Some of the pebbles are fragments of calcrete of Lower Pleistocene age (Coque, 1962).

Recent observations (Ballais, 1984; Ballais etal., 1988) distinguished the following:

- a terrace with a complex composition consisting of silts sometimes gypseous and rare conglomeratic lenses with two calcrete separated by a gypcrete. This unity is probably Middle Pleistocene.

- a terrace, about $4 \mathrm{~m}$ high consisting of lenses of conglomerates or coarse-grained friable deposits, alternating with silts and calcareous concretions. This unity is probably Upper Pleistocene.

- a terrace with thick deposits of about 2 m consistIng of coarse-grained lenses and sandy with silty lenses. This unity is probably of Holocene age.

THE MATMATA BASINS (Coude-Gaussen et al., 1984)

Perldesertic loess deposits consisting of very fine sands and silts mainly quartzeous are deposited 
within the basins on the Matmata Plateau. These loess with a thickness that can attain $20 \mathrm{~m}$, contain 4 to 5 altered layers. This represents $\mathrm{BCa}$ accumulation carbonate horizon with calcareous concretions of different facies (nodules, friable crust, more or less continuous thin flagstone). An upper Pleistocene age is attributed to this loess. In fact, the most recent three paleosolls levels have been dated by ${ }^{14} \mathrm{C}$ as between 10000 to 32000 years B.P. The most ancient two levels are situated time-wise above the ${ }^{14} \mathrm{C}$ limit. Towards the western and eastern borders of the Matmata Plateau, the loess diminish in thickness and become more gypseous. Unconformities represented by erosional glacis replace the calcretes and the paleosoils towards the east whereas to the west gypcretes progressively appear.

However, recent studies in and around the Matmata Plateau (Kammoun et Ben Ouezdou, 1984; Ben Ouezdou et Zouari, 1986; Zouari et al., 1986, Ben Ouezdou, 1988) do not entirely confirm these stratigraphic datings particularly as the ${ }^{14} \mathrm{C}$ datings were obtained from calcareous concretions which are extremely unreliable. Indeed, the nodules silts and calcretes are always superposed at the top of the high terrace without ever fit together with it. This high terrace dates to final Acheulian (Ben Ouezdou, 1986). The silts and sands were probably deposited before the downcutting of the high terrace, towards the end of the Middle Pleistocene. The main depositional phase of the silts and sands was probably at the end of the Middle Pleistocene. This does not exclude the possibility of silt deposition during the Upper Pleistocene (Ben Ouezdou, 1986).

\section{THE GABES COASTAL PLAIN (Ben Ouezdou, 1984, 1986, 1987)}

\section{The Pliocene-Quaternary boundary}

The Pliocene-Quaternary boundary in the Gabès coastal plain does not display any unconformity. The continuity of detritic continental sedimentation (clays, sands and conglomerates) results in a gradual indistinct passage between the Tertiary and the Quaternary.

\section{The Lower Pleistocene}

An ablation glacis cut down into gypseous clays, sands and conglomerates is probably of Lower Pleistocene age. Strongly dissected by the hydrographic network and reduced to scattered mounds and interfluvial patches, this glacis is covered by a conglomerate with calcareous cement of about $0.5 \mathrm{~m}$ thickness. A salmon calcrete overlies the conglomerate. It is relatively well preserved in the pledmont zone but becomes more and more broken up towards the coast where it is replaced by a more recent gypcrete.

\section{The Middle Pleistocene}

A high terrace lies within the Lower Pleistocene glacis and corresponds to a deposit of $5 \mathrm{~m}$ maximum thickness, very heterogenous consisting of blocks, pebbles and fine to coarse sands. Semi-flat and rounded pebbles are predominant within this deposit originating from the generally clacareous and dolomitic terrain of the Matmata Plateau. The red and beige silt lenses with calcareous concretions of varying degree of development are intercalated within the coarser-grained deposits. The degree of consolidation increases upwards. At the top of the deposits, a calcrete developed in layers or as slabs or more frequently as conglomerate. In places, silts also contain a calcrete and systematically superposed coarse-grained deposits and the cover of the Lower Pleistocene glacis. The Middle Pleistocene dating of this complex is due to final Acheulian industry and the existence of Mousterian industry at the base of the middle terrace (see below).

\section{The Upper Pleistocene and the Holocene}

A middle terrace or an accumulation glacis is enclosed within the two most ancient levels and consists of deposits of variable thickness (3 to $15 \mathrm{~m}$ ) made up of silty material and gypseous clays. Coarse-grained lenses (rudites) are intercalated within this fine series. Occasionally, an erosional level often marked by gypcrete pebbles helps to distinguish two members within this complex. At the top, a crust with variable thickness develops (ranging from several centimeters to $1,5 \mathrm{~m})$. The visible base of the deposits dated as 28000 years B.P. $\left({ }^{14} \mathrm{C}\right)$ revealed a Mousterian industry (Gobert,1962; Page, 1983; Fontes et al., 1983). Towards the top, a lithic industry was ascribed to Ibéromaurusian (Gobert, 1962). Recently it has been ascribed to a southern Capsian facies (Ben Ouezdou et al. 1986). The deposition was completed about 8000 years B.P. (Lower Holocene) (Fontes et al., 1983).

A lower terrace, which has been reduced to a bench upstream. generally increases in importance downstream. The deposits which are about 2 $m$ in thickness become increasingly coarser-grained longitudinally. It consists of pebbles, gravels and occasional blocks at the exit of the mountain system becoming increasingly fine grained (sandy) downstream. The deposition which is dated at the base as $5195 \pm 105$ years B.P. (Steinman und Bartels, 1982), continues during the historic period as evident by the discovery of fragments of pottery at the top of the terrace. 


\section{PROBABLE CORRELATIONS}

\section{General Characteristics (see Table)}

The Pliocene-Quaternary boundary is characterized by its complexity (Riser, 1979). It still presents the characteristic of the Tertiary era particularly with regard to the continuation of the sedimentation at the Continental Terminal summit. Two facies can be distinguished: a fluviatile detritic facies in the Gabès coastal plain and the AurèsNemencha piedmont; as well as a lacustrian facies in the centre of the basin of large Algero-Tunisian saline lakes. On the other hand, characteristics typical of the Quaternary era are present, particularly with regards to the crusts which correspond to a characteristic regional repartition or distribution. The gypcrete at the top of the Continental Terminal is centered around the Tunisian salt lakes, Nemencha (Cabot, 1971), and the eastern part of the southern piedmont of
Aurès. On the contrary, at the same period, the calcretes covered all the other surfaces studied. Finally, the types and number of forms become progresstvely simple from west to east (see Table). It is strongly probable that this simplification is related to regional features due to tectonism, as well as to altitude and energy of relief.

The Middle Pleistocene is generally characterized by the development of accumulation forms and gypcretes. The accumulation glacis, "épandages", fans (Aurès, Nemencha) and terraces (Dahar, Gabès coastal plain) gradually replaced ablation forms (covered ablation glacis) which are located in the region of the great Tunisian saline lakes. The gypcretes spread globally at the expense of the calcretes in a rather complicated manner. This is obvious toward the west where there is a tendency to replace calcretes on the south Aurasian piedmont. On the contrary, on the west-ern flank of Dahar, a gypcrete is intercalated between two

Synthetic table of continental guaternary forms and deposits of the Saharan margin of eastern Maghreb.

Tableau synthétique des formes et dépôts du Quaternaire continental du Maghreb oriental.

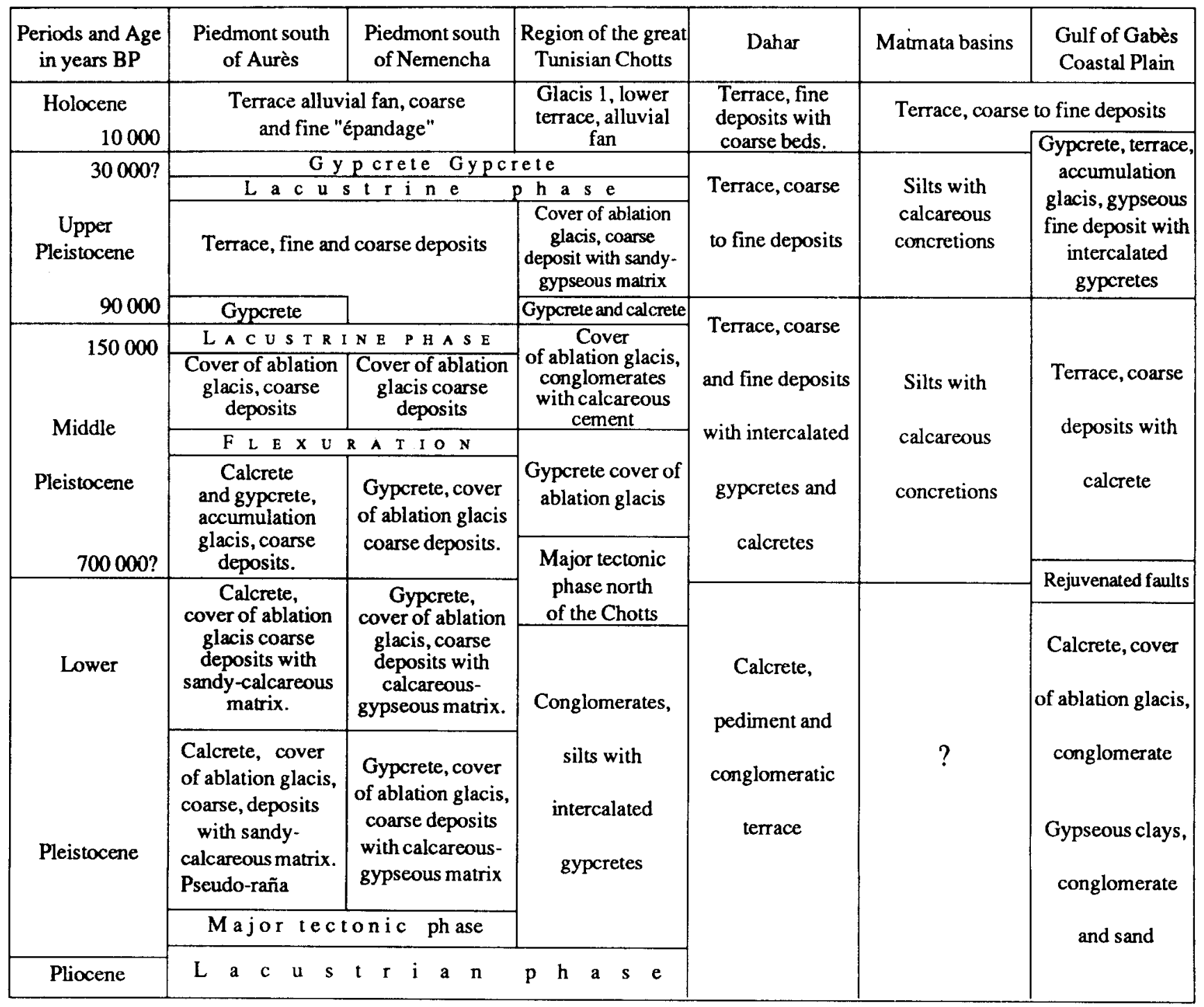


calcretes and on the southern piedmont of the Fejaj saline lake, a calcrete, on the other hand, consolidates the cover of the glacis 3 . However, in the Gabès coastal plain and the Matmata troughs, there is also the formation of calcretes.

The Uppermost Pleistocene-Holocene is characterized by the predominance of accumulation forms (terraces, alluvial fans, "épandages", etc..) throughout the flank of the Sahara with the exception of the region around the large Tunisian saline lakes. One form only can be distinguished during the Upper Pleistocene in a general sense. This is a terrace. Similarly, the gypcretes totally dominate during the Upper Pleistocene with the probable exception of the Matmata troughs which are characterized by silts with calcareous concretions. These gypcretes disappeared during the Lower Holocene. The granulometry of the Upper Pleistocene deposits becomes finer following a west-east gradient and persists during the Holocene with the exception of terrace $I$ of Aurès and glacis 1 of the large Tunisian saline lakes. Finally, a lacustrian phase that can be attributed to the Upper Pleistocene develops within the basin of the Algero-Tunisian large saline lakes.

\section{DISCUSSION}

During the Quaternary, the passage is generally from levelling forms to accumulation forms. Indeed, covered ablation glacis or less frequently. pediments are replaced by terraces, alluvial fans and "épandages".

A prior, this type of substitution could only be the effect of shortening of the evolution time after the Lower Pleistocene. This does not mean much as it is not possible to conclude that the genesis of the accumulation forms is more rapid than that of the erosional forms. In addition, it is not also possible to conclude that this genesis is a necessary stage in the development of the erosional forms.

However, even if this substitution is general, it is not concomitant everywhere. This morphologic breake overlaps in time into three phases in the six regions. In effect, for the entire Gabès coastal plain-basins of Matmata-Dahar, the break is situated between the Lower Pleistocene and the Middle Pleistocene. On the other hand, for the southern piedmont of Aurès and Nemencha, the passage from erosional to accumulation forms occurred at the end of the Middle Pleistocene whereas in the region of the great Tunisian Chotts, this took place at the end of the Upper Pleistocene. This highlights the originality of the great Tunisian Chotts. This difference could be explained by a difference in the tectonic evolution of the three units. The erosional forms followed major tectonic phases in the piedmont south of Aurès and Nemencha as well as in the region of the great Tunisian Chotts. The overlap in time between the Dahar-basins of Matmata-coastal plain of Gabès on the one hand and the piedmont south of Aurès and Nemencha as well as the region of the great Tunisian Chotts on the other hand, may be explained by the age of different geological structures. As the first group is relatively old, the second group is relatively young. Within the second group, the overlap in the break between the great Tunisian Chotts and the pledmont south of Aurès and Nemencha may be explained by the overlap in the beginning of the major tectonic phase (see Table).

From the sedimentologic point of view, the deposits are generally coarse-grained (rudites) during the Middle Pleistocene. On the contrary, they become dominantly fine (lutites or arenites $<500 \mu \mathrm{m}$ ) during the Upper Pleistocene and the Holocene with the exception of the great Tunisian Chotts. This also constitutes an additional evidence in support of the originality of the region of great Tunisian Chotts. It also confirms the existence of a major climatic break at the end of the Middle Pleistocene. The Middle Pleistocene is characterized by a climate which is more humid and aggressive than that of the Upper Pleistocene. The Middle Pleistocene was a lacustrian phase which prevalled throughout the Algero-Tunisian Chotts system (Ballais et al., 1985). T/U datings (Fontes et al., 1987) confirms this and permit the identification of a lacustrian phase during the Middle Pleistocene ( $150000-90000$ years B.P.) as in Wadi Ash-shati (Gaven, 1982) and as in the west of Algeria (Causse et al. 1988).

From the geochemical point of view, the time range of the distribution of the two basic types of crusts and encrustings reveal a high degree of complexity and evidence of the importance of regional parameters. Analysis of the distribution in time and space of these two types of crusts lead to the following conclusions:

- the Matmata basins experienced only one type of crust (calcretes) particularly during the Middle Pleistocene with the possibility of movements of carbonates during Upper Pleistocene. This region constitutes a special case on the scale of the studied zone because of the absence of gypcretes.

- In the Gabès coastal plain, there was a definite break between the Middle Pleistocene with calcretes and the Upper Pleistocene - Lower Holocene with gypcretes. This change may be related to a climatic change with a tendency towards aridity. This is because of the necessity 
for less water in the mobilization of calcium sulfate with reference to calcium carbonate.

- Dahar and the Aurès pledmont experienced only one type of crust during the Lower Pleistocene. This is the calcrete. During the Middle Pleistocene, the two types of crusts alternated without any visible break.

- Both the great Tunisian Chotts and the piedmont south of Nemencha are characterized by the development of gypcretes from the Lower Pleistocene to the Upper Pleistocene with rare apparition of calcretes.

- The alternation of both types of crusts during the Middle Pleistocene probably confirm the complexity of the climatic evolution. If this evolution is characterized by a general tendency towards aridity during the Quaternary without any regional change in the lithology (Coque, 1962; Ballais, 1984; Ben Ouezdou, 1986, 1987). the situation is different during the Middle Pleistocene when at least one humid fluctuation occasionally reversed this tendency.

The crust studied in this paper cannot be regarded as of purely pedogenetic origin and therefore intimately related to the characteristics of the substratum. On a regional scale, it has been well established in the past that most of the gypcretes, particularly those which directly overlie a non-gypseous subtratum (often calcareous) are due to fixation by vegetation of dusts taken by the wind from the Sebkhas (great Chotts) (Coque, 1962). During the Pleistocene, the development of the gypcretes at the expense of the calcretes, on the piedmont south of Aurès-Nemencha from east to west, with no modification of the substratum and the hydrographic network, is a proof that there is increase in andity (Ballais, 1985), because gypcretes advanced further and further from the great Chotts. The contemporaneous appearance of the first Quaternary wind deposits in the Ziban, just to the west, confirms this interpretation (Ballais et al. 1979). On a local scale (wadi Ahmadi on the western flank of Dahar), a gypcrete intercalates between two calcretes in the Middle Pleistocene terrace at a time when the basin is only calcareous. This crust which results from the accumulation of gypseous dust suggest a break in the supply of dissolved calcium bicarbonates which took part in the formation of the surrounding calcretes. The substitution of water transported deposits by wind transported deposits confirms a less humid climate.

\section{CONCLUSION}

This review attempts to compare with the Saharan Maghreb western and central margin regions based on the investigations of Conrad
(1969) in the Algerian Sahara, Couvreur (1978) in limestones of the Central High Atlas and Riser (1978) in the Jebel Sahrho. It certainly confirms the conclusions of the studies in the eastern Maghreb. During the Lower Pleistocene, the mountain sectors provided the rañas or the major solifluxion flows as well as the glacis or terraces with calcretes, whilst a lacustrian phase with Cerastoderma glaucum was taking place in Touat and Ahnet. The Middle Pleistocene also witnessed the development of accumulation forms such as the conglomeratic terrace of northern Sahara fans and mountain terraces with calcretes. From the Upper Pleistocene, the fans and terraces are predominantly detritic, terriginous, fluviatile and fluvio-eolian deposits silt-grained and clayey (<60 $\mu \mathrm{m})$.

It is also necessary to stress the importance of the Middle Pleistocene period and the passage to Upper Pleistocene in the Saharan flank of eastern Maghreb. In general, the end of the Middle Pleistocene is marked by fundamental breaks in morphology, sedimentology and geochemistry. Morphologic break is witnessed by the disappearance of the big ablation glacis, which were principally succeeded by terraces. The sedimentologic break is marked with the end of the exclusive predominance of coarse-grained deposits (rudites). Finally, the geochemical break is witnessed by the almost complete disappearance of calcretes and the development of gypcretes. The Middle Pleistocene is also characterized by the complexity of the observed tendencies. It is now established that a lacustrlan phase reappeared at the end of the period. This phase was traditionally attributed to the Upper Pleistocene (Coque, 1962), and seems to be quite generalized throughout northern Sahara from Libya to Erg Chech. The tendency of continuous extention of the gypcretes from Lower Pleistocene was disturbed by the development of new calcretes.

\section{REFERENCES}

Abbes, C. et Abdeljaouad, S. avec la collaboration de Ben Ouzdou, H. 1986. Carte géologique d' El Hamma au 1/ 100000 (sud tunisien). Serv. géol. Tunisie. Ballais, J.-L., Marre, A. et Rognon, P. 1979. Pérlodes arldes du Quaternatre récent et déplacement des sables éollens dans les Zibans (Algérie). Rev. Géogr. phys. et Géol dyn. (2) 21, 2, 97-108.

Ballais, J.-L. 1984. Recherches geomorphologlques dans les Aurès (Algérle). A.N.R.T., Lille, France.

Ballals, J.-L. 1985. Zonation et aridification au Quaternaire moyen dans l'Atlas saharien algérien orlental. Physto-Géo 14-15, 125-130.

Ballais, J.-L., Balland, V., Benazzouz, M. T. et Coque, R. 1985. Recherches préliminaires sur l'évolution quaternaire du Bas-Sahara algérien. In: Pour Fernand Joly, 29-39, C.E.R.G.C.G., Paris, France. 
Ballais, J.-L. 1986. Variations du milleu à l'Holocène dans les Aurès (Algérle). In: Changements globaux en Afrique durant le Quaternatre, Travaux et Doc. ORSTOM 197, 19-21.

Ballals, J.-L. et Benazzouz, M. T. 1987. Sédimentation quaternaire lacustre et éolienne dans le Bas-Sahara algêrien. 8th I.A.S. Regional Meeting of Sedim., 54-55, Tunis, Tunisle.

Ballais, J.-L., Ben Ouezdou, H., Ghanmi, M. et Regaya, K. 1988. La coupe de l'oued Ahmadi (Dahar, Sud tunisien) : son intérêt pour la comprêhension de l'êvolution climatique au Pléistocène moyen. Méditérranée 2, 52-60.

Ben Ouezdou, H. 1984. Stratigraphie des dépôts quaternaires continentaux et marins du golfe de Gabès. C.R. Ac. Sc. Paris, 299, II, 1351-1354.

Ben Ouezdou, H. 1986. Essal de corrélation des formations quaternaires continentales et marines dans les alentours du golfe de Gabès. Géodynamique 1(2), 81-95.

Ben Ouezdou, H. , Camps, G., Gragueb, A., Mahjoub, K. et Zouar1, K. 1986. Sur les dépôts du Pléistocène supérieur et de l'Holocène de la réglon des Chotts et de la plaine côtłère du golfe de Gabès (Tunisie) et leur place dans la stratigraphie du Quaternaire. C.R.AC. Sc. Paris, 302, II, 659-664.

Ben Ouezdou, H. et Zouari, H. 1986. Carte géologique de Mareth au 1/100 000. Serv. géol. Tunisie.

Ben Ouezdou, H. 1987. Etude morphologique et stratigraphique des formations quaternaires des alentours du golfe de Gabès. Rev. Sc. Terre 5, 1-165.

Ben Ouezdou, H. et Zargouni, F. 1988. Nouvelles données à propos du Quaternaire et de la tectonique récente dans la chaine de Metlaoul (sud-ouest de la Tunisie). Méditerranée 2, 22-26.

Cabot. J. 1971. Recherches morphologiques sur le piémont méridional de l'Aurès. Rev. Geom. Dyn. 3, 129140.

Causse, C., Conrad, G., Fontes, J.-C., Gasse, F., Gibert E. et Kassir, A. 1988. Le dernier khumide" pléistocène du Sahara nord-occidental dateralt de 80-100000 ans. C.R. Ac. Sc. Paris, 306, II, 1459-1464.

Causse, C., Coque, R., Fontes, J.-C., Gasse, F., Ben Ouezdou, H. and Zouari, K. in press. Two high levels of continental waters in southern Tunisia about 90 and $150 \mathrm{ka}$.

Conrad, G. 1969. L'évolution continentale post-hercynienne du Sahara algérien (Saoura, Erg Chech-Tanezrouft, Ahnet-Mouydir). C.N.R.S., Paris, France.

Coque, R. 1962. La Tunisie prèsaharienne, étude géomorphologique. A. Colin, Paris, France.

Coque, R. et Gachelin, C. 1975. Problèmes géomorphologiques du Bas-Sahara algéro-tunisien. In: Mélanges offerts à G. Viers, 161-169. Univ. Toulouse-Le Mirail, France.
Coudé-Gaussen, G., Le Coustumer, M. N. et Rognon, P. 1984. Paléosols d'äge pléistocène supérleur dans les loess de Matmata (Sud tunisien). Sc. Geol 37(4), 359386.

Couvreur, G. 1978. Essal surl'évolution morphologique du Haut Atlas central calcaire (Maroc). A.N.R.T., Lille, France.

Fontes, J.-C., Coque, R., Dever, L., Filly, A. et Mamou, A. 1983. Paléohydrologie isotopique de l'oued Akarit (Sud tunisien) au Pléistocène supérteur et à l'Holocène. Paleog., Paleoel., Paleoecol. 43, 41-62.

Fontes, J.-C., Gasse, F., Ben Khelifa, L., Zouari, K., Ben Ouezdou, H., Zaouall, J., Carbonel, P. et Causse, C. 1987. Programme Palhydaf. Etat d'avancement, site I: Tunisie meridionale. In: Sém Paléolacs -Paléoclimats en Am. lat. et en Afr. (20000 ans B.P. -Actuel), 1, Bondy, France.

Fontes, J.-C., Gasse, F., Zouari, K., Ben Khelifa, L., Ben Ouezdou, H., Carbonel, P., Causse, C., Thouveny, N., Tucholka, P. and Zaouali, J. 1987. Lacustrine sediments from wadi El Akarit and Chott Fejaj (south Tunisia) since 140000 B.P. In: Symp. Palaeocl. and environm. reconst. from lacust. basins, 1 . Strasbourg, France.

Gaven, G. 1982. Radiochronologie isotopique. In: Le Shati, lac pléistocène du Fezzan (Libye) (Ed. par Petit-Maire, N.), 44-55, Paris France.

Gobert, E. G. et Howe, B. R. 1952. L'Ibéro-maurusien de l'oued El Akarit (Tunisie). In: Actes Ilème Cong. panaf. préh. 575-598, Alger, Algérie.

Gobert, E. G. 1962. La préhistoire dans la zone littorale de la Tunisie. Quaternaria IV, 271-307.

Guiraud, R. 1973. Evolution post-triasique de l'avantpays de la chaîne alpine en Algérie d'après l'ètude du bassin du Hodna et des régions voisines. Thèse doct. ès-Sciences, Nice, France.

Kammoun, Y. et Ben Ouezdou, H. 1984. Le Quaternaire du Golfe de Gabès, Monts de Matmata et plaine côttère (Tunisie orientale). In: lOème R.A.S.T., 313, Soc. géol. France, Paris, France.

Page, W. D. 1983. The geological setting of the archaeological site at oued El Akarit and the palaeo-climatic significance of gypsum soils, southern Tunisia. Serv. géol., Tunis, Tunisie.

Riser, J. 1978. Le jbel Sarhro et sa retombée saharienne (Sud-Est marocain). Etude géomorphologlque. Thèse Doc. ès-Lettres, Aix-en-Provence, France. . Riser, J. 1979. La période charnière entre Pliocène et Quaternaire. Bull. Ass. géogr. fr. 462, 229-233.

Steinmann, S. und Bartels, G. K. 1982. Qüartargeomorphologische beobachtungen ans nord und sud Tunisien. Catena 9, 95-108.

Zouari, H., Kammoun, Y. et Regaya, K. 1986. Carte géologique de Matmata au $1 / 100000$ (sud tunisien). Serv. géol. Tunisie. 